\title{
FINITE ELEMENT ANALYSIS OF MATERIAL EVALUATION FOR LIGHT WEIGHT VEHICLE MONO COMPOSITE LEAFSPRING
}

\author{
DR. P. NANDA KUMAR
}

Professor, Department of Mechanical Engineering, NBKR Institute of Science \& Technology, Andhra Pradesh, India

\section{ABSTRACT}

The composite materials emerging as more promising materials the automotive industry is looking to substitute the materials for the existing parts to reduce the weight and achieve the other benefits. The strain absorbing the elastic energy of these composite materials and weight to strength can be improved with altering the matrix and reinforcement combinations. The possibility of stiffness and load carrying capacity can be improved with weight reduction. The conventional leaf spring of SCV is selected for the analysis. Three different composite materials have been considered. They are E-glass/epoxy, graphite/epoxy and carbon/epoxy. The three mono composite leaf springs have been modeled by considering uniform thickness and uniform width cross- section. After modeling, static and dynamic analysis has been done using ANSYS FEA software and the results are compared with the analytical results. It is found that among the three different composite leaf springs, steel leaf spring can be replaced by E-glass / epoxy mono-composite leaf spring as the stresses are lower than the steel leaf spring and the stiffness is nearly equal. The stress is within the yield strength limit. The ANSYS results show that the weight of leaf spring reduced to $85 \%$ with E-Glass/Epoxy Mono composite leaf spring.

KEYWORDS: Leaf Spring, Composite Materials, FE Analysis

Received: Nov 07, 2020; Accepted: Nov 27, 2020; Published: Dec 05, 2020; Paper Id.: IJMPERDDEC202012

\section{INTRODUCTION}

Ever increasing demands of high performance together with long life and light weight necessitate consistent development of almost every part of the automobile. Apart from their shape and geometry, on which the performance characteristics of the automobile largely depend, their stiffness is of considerable importance. The need of alternative and conservation, natural resources and economize the performance of the product the automotive industry is looking for the weight reduction. The achievement of reduction in weight by substituting the alternative materials, optimizing the design process and with better processing techniques. The inspiring weight of the leaf spring is another key point which attributes 10 to $20 \%$ of the weight. This yields to develop the vehicle with better riding quality. The main function of the springs absorbs store and release the shock energy. The new material strain energy plays a primary aspect in the design process. It can be easily observed that material having a lower modulus and lower density will have a greater specific strain energy capacity

The relationship of the specific strain energy can be

$$
\mathrm{U}=\sigma^{2} / \rho \mathrm{E}
$$

Where $\sigma$ is the strength, $\rho$ the density and E the Young's modulus of the spring material. The fig.1. 
describes the design of steel leaf spring used for the present work.

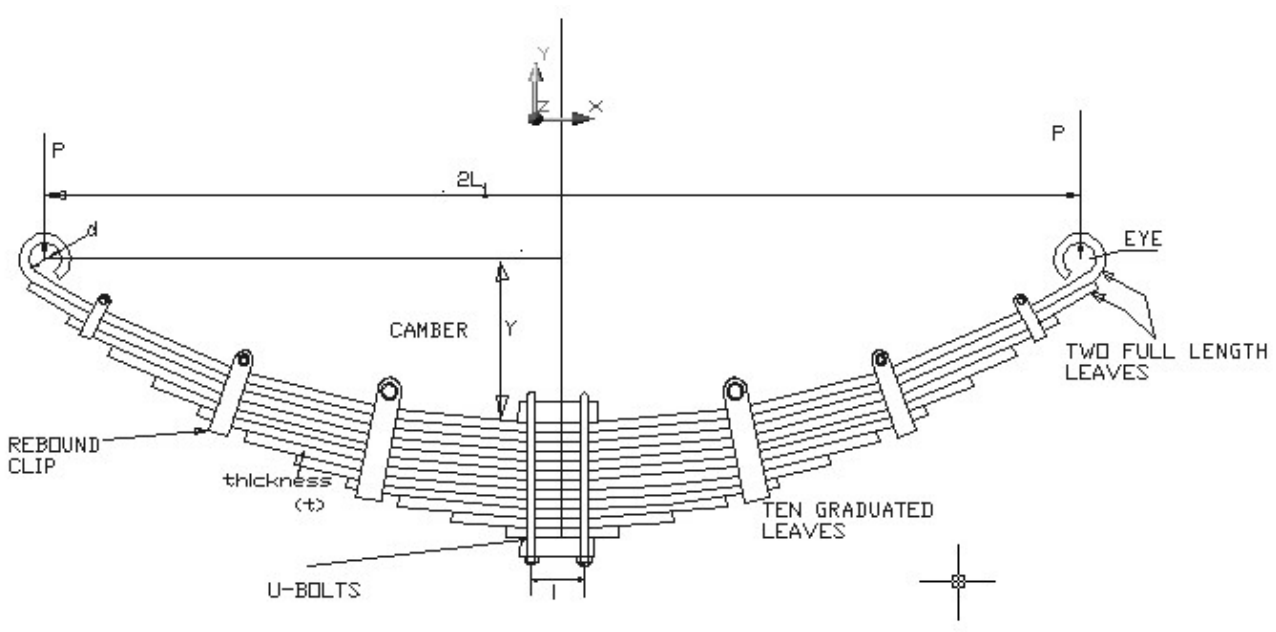

Figure 1: Leaf spring of Automobile

J. Hou et al. FEA results show inter laminar shear stress concentration existing at the end of the fibers going around the eye and rejoining the body, leading to a local delamination. However, this did not have any effect on the static proof loading of the suspension nor on its fatigue life. Mouleeswaran senthil kumar et al steel leaf spring static and fatigue analysis are compared with multi leaf spring of polymer reinforced with glass fiber. Concluded that fatigue life of composite is more than that of conventional steel leaf spring. kiran $\mathrm{k}$. Jadhao et al concludes that the composite can be used for leaf spring for the light vehicle and meet the requirement, together with the sustainable weight reduction. Better agreement between experimental result and fea is observed Trivedi achyut $\mathrm{v}$ et al. carried static analysis of the composite leaf spring and found that composite leaf springs are good. Pradeep b. Tapkir et al. predict the fatigue life cycle for crack initiation at a maximum stress location in the e glass epoxy leaf spring. M. Sai Kumar et al. discussed the static analysis of a leaf spring with 10 layers for the materials low carbon steel, high carbon steel, Inconel and multi material leaf springs. By analyzing the design, it is found that all the stresses in the leaf spring are well within the allowable limits and with good factor of safety for the materials high carbon, Inconel and multi-layer metals. Prasad P. Kunzarkar et al. reviewed conventional steel leaf springs with different composite leaf spring analysis and concluded that the composite material leaf spring are more efficient and beneficial for the light passenger vehicles.

\section{SPECIFICATION OF THE PROBLEM}

The objective of the present work is to select best suitable composite material for the leaf spring. The multi leaf spring is to be replaced Mono leaf spring. The existing steel leaf spring is first analyzed and this analysis results are used to compare with Mono composite leaf spring analysis. The composite leaf spring is designed and analyzed with different unidirectional Glass Fiber/Epoxy, Carbon fiber/Epoxy and Graphite/Epoxy. Then the above leaf springs are compared to select best composite material for leaf spring.

\section{DESIGN PARAMETERS OF STEEL AND MONO COMPOSITE LEAF SPRING}

Parameters of the steel leaf spring used in this work are shown in Table 1.The material Properties of steel leaf spring are presented in the Table.2.The Material Properties of composite leaf springs are presented in the table.3. 
Table 1: Parameters of the steel leaf spring

\begin{tabular}{|l|l|}
\hline \multicolumn{1}{|c|}{ Model } & CDR 650MD 2WD \\
\hline Suspension & REAR LEAF \\
\hline Span length & $1120 \mathrm{~mm}$ \\
\hline Thickness & $6 \mathrm{~mm}$ \\
\hline Width & $50 \mathrm{~mm}$ \\
\hline Outer eye dia & $50 \mathrm{~mm}$ \\
\hline Dia.of centre bolt & $8 \mathrm{~mm}$ \\
\hline Camber & $180 \mathrm{~mm}$ \\
\hline Ineffective length & $100 \mathrm{~mm}$ \\
\hline Total no. Of leaves & 10 \\
\hline No. Of full length leaves & 2 \\
\hline No. Of graduated leaves & 8 \\
\hline Vehicle weight & $1910 \mathrm{Kg}$ \\
\hline
\end{tabular}

Table 2: Material Properties of steel leaf spring

\begin{tabular}{|l|l|}
\hline \multicolumn{1}{|c|}{ Material selected } & \multicolumn{1}{c|}{ Manganese Silicon Steel (Steel 55Si2Mn90) } \\
\hline Young's Modulus E & $2.1 \mathrm{E} 5 \mathrm{~N} / \mathrm{mm}^{2}$ \\
\hline Density & $7.86 \mathrm{E}-6 \mathrm{~kg} / \mathrm{mm}^{3}$ \\
\hline Poisson's ratio & 0.3 \\
\hline Tensile stress & $1962 \mathrm{~N} / \mathrm{mm}^{2}$ \\
\hline Yield stress & $1470 \mathrm{~N} / \mathrm{mm}^{2}$ \\
\hline
\end{tabular}

Table 3: Material Properties of composite leaf springs

\begin{tabular}{|l|l|l|l|}
\hline & E-Glass/Epoxy & \multicolumn{1}{|c|}{ Graphite/Epoxy } & \multicolumn{1}{|c|}{ Carbon/Epoxy } \\
\hline Extensional Elastic Modulus, $\mathrm{E}_{1}, \mathrm{MPa}$ & $43 \mathrm{E} 3$ & $294 \mathrm{E} 3$ & $177 \mathrm{E} 3$ \\
\hline Transverse Elastic Modulus, $\mathrm{E}_{2}, \mathrm{MPa}$ & $9 \mathrm{E} 3$ & $6.4 \mathrm{E} 3$ & $10.6 \mathrm{E} 3$ \\
\hline In-Plane Shear Modulus, MPa & $4.5 \mathrm{E} 3$ & $4.9 \mathrm{E} 3$ & $7.6 \mathrm{E} 3$ \\
\hline Major Poisson's Ratio, $v_{1}$ & 0.27 & 0.23 & 0.27 \\
\hline Minor Poisson's Ratio, $v_{2}$ & 0.06 & 0.01 & 0.02 \\
\hline Density, $\rho, \mathrm{Kg} / \mathrm{m} 3$ & 2000 & 1590 & 1600 \\
\hline Yield Strength, $\mathrm{MPa}$ & 2000 & 2067 & 1900 \\
\hline
\end{tabular}

\section{DESIGN OF MONO COMPOSITE LEAF SPRING}

The leaf spring is used in most of the automobile vehicles are exposed to different load conditions. To overcome interleaf spring behavior mono leaf spring model is considered for the design of composite material. The thickness of mono leaf composite is varied, keeping the width and length constant for sustainability. To compare the results similar load and boundary conditions are used. The stiffness of steel leaf spring is $32 \mathrm{~N} / \mathrm{mm}$. The thickness of mono composite leaf spring is computed by using formula (1) for the same stiffness of steel leaf spring

$$
\Delta=\left(4 \mathrm{FL}^{3}\right) / \mathrm{E}_{\mathrm{m}} \mathrm{BT}^{3}
$$

Where $\Delta=$ Deflection of the beam

$\mathrm{F}=$ Load on the beam

$\mathrm{L}=$ length of beam

$\mathrm{B}=$ width of beam

$\mathrm{T}=$ thickness of beam

The thickness of E-Glass/Epoxy, Carbon/Epoxy and graphite epoxy are $21.50 \mathrm{~mm}, 13.68 \mathrm{~mm}, 11.55 \mathrm{~mm}$ 
respectively.

\section{FINITE ELEMENT ANALYSIS}

The leaf spring of composite material is modeled and analysed using ANSYS software. An 8 node 3D brick element solid 45 used for meshing the model and contact surface is modeled with 5 node contact element contact 49 used for contact and sliding behavior of leaf spring. The finite element results of steel leaf spring and mono composite leaf springs are compared. Figs. 2 to 13 represent FEA results for steel and mono composite leaf spring.

\subsection{Static analysis}

The FE analysis for stress distribution and deformation

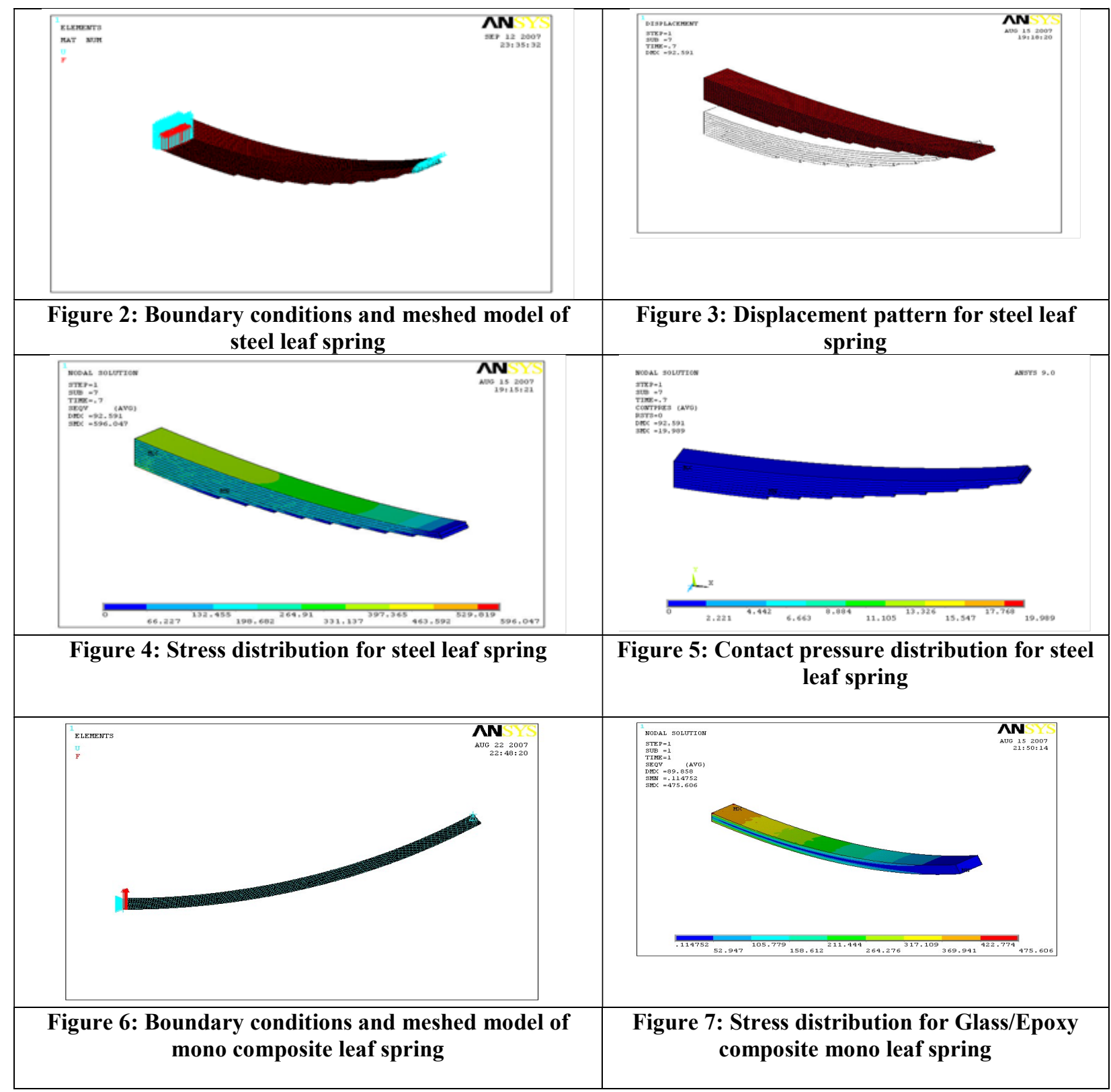




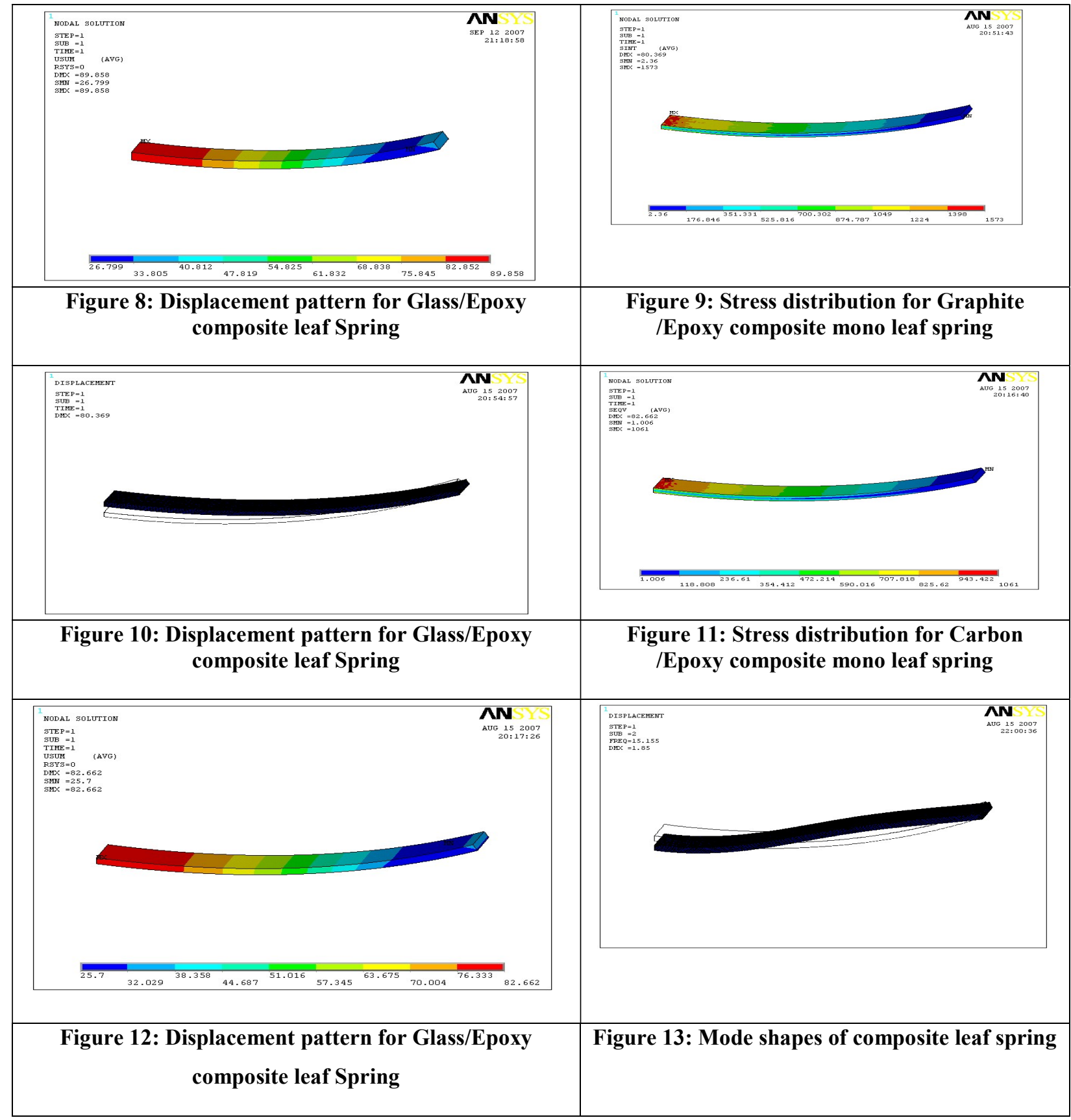

\section{RESULTS AND DISCUSSIONS}

Steel leaf spring was modeled and analyzed using ANSYS 9.0. Further, a mono composite leaf spring was modeled for the same stiffness as that of the steel leaf spring for the same load carrying capacity and boundary conditions. A load of $3300 \mathrm{~N}$ was applied in both the cases. The constraints are, the front eye is constrained as UY, UZ and the nodes at the middle are constrained as UX, UZ. For all the three composite leaf springs same design specifications of steel leaf spring except thickness, was considered. Static and modal analyses are performed by using ANSYS 9.0. The results Maximum deflection $(\mathrm{mm})$, Maximum stress (MPa) and Stiffness $(\mathrm{N} / \mathrm{mm})$ of ANSYS are presented in the table.4 for comparison.

Table 4: Comparison of ANSYS results with theoretical values

\begin{tabular}{|c|c|c|c|c|c|}
\hline Material & $\begin{array}{c}\text { Maximum deflection } \\
(\mathbf{m m})\end{array}$ & $\begin{array}{c}\text { Maximum stress } \\
(\mathrm{MPa})\end{array}$ & Stiffness(N/mm) & $\begin{array}{c}\text { Weight } \\
(\mathrm{N})\end{array}$ & $\begin{array}{c}\text { Percentage } \\
\text { Weight }\end{array}$ \\
\hline
\end{tabular}




\begin{tabular}{|l|l|l|l|l|l|l|l|l|}
\hline & $\begin{array}{c}\text { Theoretic } \\
\text { al }\end{array}$ & \multicolumn{1}{|c|}{ ANSYS } & $\begin{array}{c}\text { Theoretic } \\
\text { al }\end{array}$ & \multicolumn{1}{|c|}{ ANSYS } & $\begin{array}{c}\text { Theoretica } \\
\text { l }\end{array}$ & \multicolumn{1}{|c|}{ ANSYS } & \multicolumn{1}{|c|}{ reduction } \\
\hline Steel & 102.20 & 92.591 & 621.60 & 596.05 & 32.28 & 35.60 & 88.290 & -------- \\
\hline $\begin{array}{l}\text { E- } \\
\text { glass/epoxy }\end{array}$ & 108.48 & 89.858 & 479.74 & 475.60 & 30.42 & 36.72 & 12.528 & 85.00 \\
\hline $\begin{array}{l}\text { Carbon } \\
\text { /epoxy }\end{array}$ & 102.20 & 82.662 & 1184.00 & 1061.00 & 32.28 & 39.92 & 5.133 & 92.94 \\
\hline $\begin{array}{l}\text { Graphite/epo } \\
\text { xy }\end{array}$ & 102.20 & 80.369 & 1662.00 & 1573.00 & 32.28 & 41.06 & 6.233 & 94.18 \\
\hline
\end{tabular}

From the results of static analysis of steel leaf spring, it is seen the displacement of the leaf spring is $92.591 \mathrm{~mm}$ which is well below the chamber length of leaf spring (i.e. 180mm). The max deflection of mono composite leaf springs is comparing their theoretical values and presented in the fig14. The ANSYS values are showing lesser than the theoretical values. The Graphite/epoxy leaf spring showing more deviation. The max stress on mono composite leaf springs is comparing their theoretical values and presented in the fig15. The ANSYS values are steel and E-glass/epoxy showing closer to the theoretical values. The Carbon /epoxy leaf spring max stress showing more deviation. The stiffness of mono composite leaf springs are compare their theoretical values and presented in the fig 16 . The ANSYS values are showing lesser than the theoretical values. The Graphite/epoxy leaf spring showing more deviation and steel leaf spring showing lower deviation. The carbon /epoxy leaf spring was effecting much weight reduction than the remaining other two.

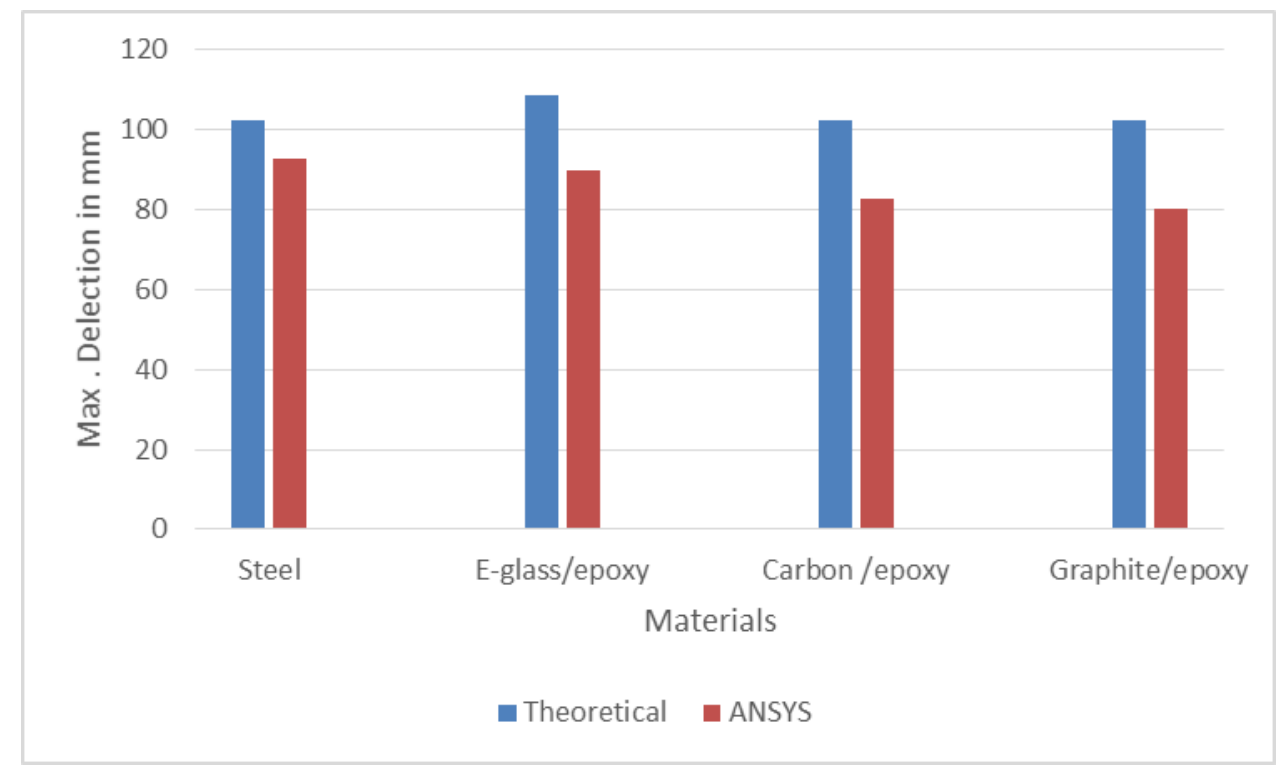

Figure 14: Comparison ANSYS results with theoretical values of Max deflection 


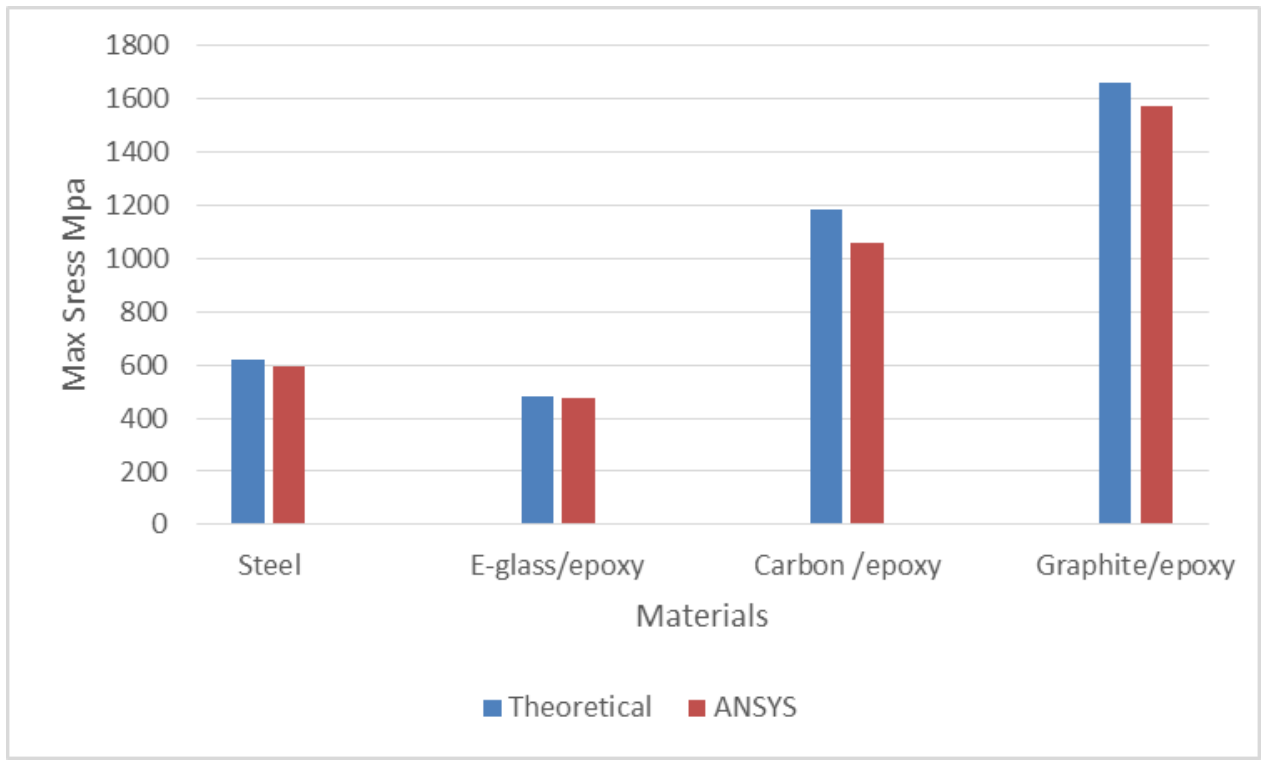

Figure 15: Comparison ANSYS results with theoretical values of Max stress

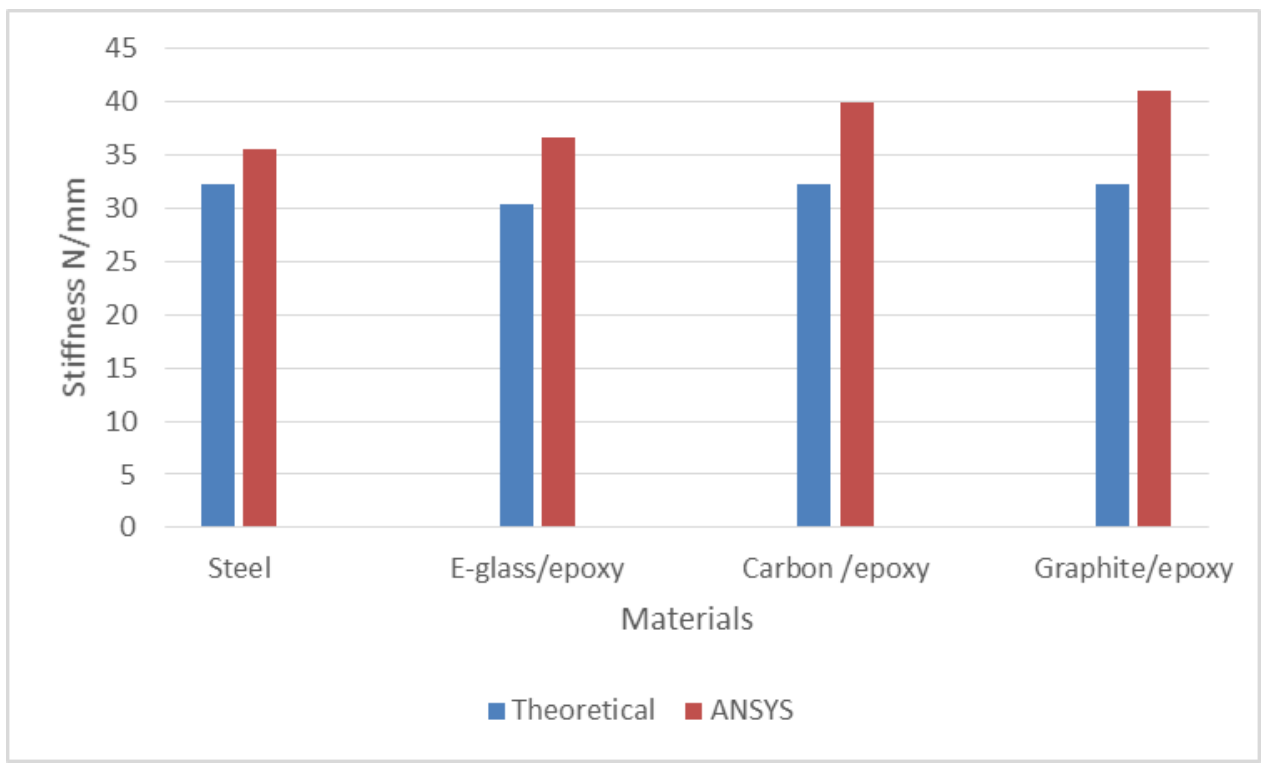

Figure 16: Comparison ANSYS results with theoretical values of stiffness

\section{CONCLUSIONS}

- The 3-D modeling of both steel and mono composite leaf spring is done and analysed using ANSYS.

- The composite leaf spring is modeled for the same stiffness as that of the steel leaf spring. The finite element analysis predicted that mono composite leaf springs are bearing good stiffness characteristics.

- All the FEA results are compared with the theoretical results and it is found that they are within the allowable limits and nearly equal to the theoretical results.

- From the static analysis results it is found that there is a maximum displacement of $92.591 \mathrm{~mm}$ in the steel leaf spring and the corresponding displacements in E-glass / epoxy, graphite/epoxy, and carbon/epoxy are $89.858 \mathrm{~mm}$, 
$80.369 \mathrm{~mm}$ and $82.662 \mathrm{~mm}$. It is found that all the values are within camber length for giving load $3300 \mathrm{~N}$.

- A comparative study has been made between composite and steel leaf spring with respect to weight and strength The mono composite leaf springs are showing an attractive weight reduction, where E-Glass/Epoxy mono composite leaf spring more reduction in weight in comparison with other two composite materials.

- From the results, it is observed that the composite leaf spring is lighter than the conventional steel spring with similar design specifications.

- Among the three composite leaf springs, E-glass/epoxy composite leaf spring has lower stresses than the steel leaf spring.

- E-glass/epoxy composite leaf spring can be suggested for replacing the steel leaf spring both from stiffness and stress point of view.

\section{REFERNCES}

1. J. Houl and g. Jeronimid Finite element aided design evolution of composite leaf spring applied mechanics and materials vols. 3-4 (2005) pp 429-434 online: 2006-08-15 (C) (2005) trans tech publications, Switzerland

2. Mouleeswaran senthil kumarl *, Sabapathy vijayarangan Analytical and experimental studies on fatigue life prediction of steel and composite multi-leaf spring for light passenger vehicles using life data analysis ISSN 1392-1320 materials science (medžiagotyra). Vol. 13, no. 2. 2007. Pp 141-146

3. Kiran k. Jadhaol, rajendra s. Dalu Analytical and experimental studies on steel and composite mono leaf spring iosr journal of mechanical and civil engineering (iosr-jmce) e-ISSN: 2278-1684,P-ISSN: 2320-334x, volume 13, issue 1 ver. Vi (jan-feb. 2015), pp 09-14

4. Trivedi achyut v., prof. R.M. Bhoraniya Static and dynamic analysis of automobile leaf spring (tata ace)ijste - international journal of science technology \& engineering | volume 1 | issue 11 | may 2015 ISSN (online): 2349-784x pp 151-156

5. Pradeep b. Tapkir, prof. Balaji nelge Fatigue life prediction of composite semi-elliptical leaf spring for heavy vehicle international journal of engineering sciences \& research technology ISSN: 2277-9655 june 2015 pp 194-199

6. M.sai kumar1, dr c.bhaskara reddy Modelling and structural analysis of leaf spring using finite element method international research journal of engineering and technology (irjet) E-ISSN: 2395-0056 volume: 04 issue: 12 | dec-2017 P-ISSN: 2395-007 pp1155-1161

7. Prasad P.Kunzarkar, Prof. Tushar V.Gujrathi: A Review on Automotive Car Composite Leaf Spring Design and Optimization International Journal of Recent Development in Engineering and Technology Website: www.ijrdet.com (ISSN 23476435(Online) Volume 7, Issue 4, April 2018) 